Karolina Dębska

University of Warsaw

k.debska@uw.edu.pl

\title{
Dominating and peripheral cultures in translation vs. translator's status
}

In his book, Lawrence Venuti [2008] sketches the situation of translation and translators in Great Britain and the United States. He suggests links between some factors concerning translation: the cultural hegemony of the US and the UK; the prevalent style adopted in texts written in English, originals and translations alike; and the situation of the translator and the translation market [Venuti, 2008: 1-34].

The nature and direction of influence between these factors is not always clear in his reasoning, but in the most general terms it would seem that, in Venuti's views, the poor situation of translators and translations in Britain and America is caused by their tendency to domesticate texts, to avoid foreignness and to treat their values as the ultimate criterion of text assessment. According to Venuti, translations are domesticated in the US and the UK because America and Britain occupy a hegemonic position in the world economy, politics, and culture [Venuti, 2008, see particularly pages 12-13], and the main criterion of text quality assessment in the countries is fluency [Venuti, 2008, see particularly pages 1-6].

The American cultural hegemony, argues Venuti, caused a loss of interest in foreign cultures, which in turn led to a decrease in the number of translations and a decline of the legal and financial status of translators (especially given that the Western idea of authorship is extremely restrictive). The hegemony also made Americans impose their own values on foreign texts - thus domesticating them, and expect them to be domesticated. It makes translations even more marginal, which creates a vicious circle [Venuti, 2008: 1-34]. 


\section{Aim and structure of the paper}

From the brief description of Venuti's reasoning presented above it would follow that in less hegemonic and more peripheral cultures, with a bigger translation market and a tolerance for foreignness, the situation of the translator should be better. In my paper, I shall test the hypothesis using the same factors Venuti discusses in his work [2008: 1-34]: cultural position of a country (in the case of Poland peripheral), the prevailing mode of writing and therefore translating, the size and strength of the translation market, and the legal and financial status of the translator. Each of these factors will be analysed in turn: ${ }^{1} \mathrm{I}$ will begin with the styles that dominate in Polish texts; and the prevalent strategies used in translations into Polish; next, I will discuss the status of translation criticism; finally, I will present the situation on the translation market in Poland and the financial and social status of the translator.

\section{Dominating style}

Venuti writes that in the $20^{\text {th }}$ century America and Britain, especially after World War II, there was a special focus on scientific research, communication technologies, and entertainment industry, which were characterised by transparent plain style whose only point was effective communication [Venuti, 2008: 5]. Elsewhere in the book, he looks for the roots of the plain styles' dominance even earlier in British history: in $17^{\text {th }}$-century belles lettres [Venuti, 2008: 35 and ff.]. Soon plain style was expected in other domains as well, also in fiction, and therefore in translation of all texts into English. Fluency and transparency became the basic criteria of text quality assessment [Venuti, 2008: 1 and ff.].

In Polish the situation is different. Firstly, it is difficult to state that any one style dominates in written texts. The Polish scholars do consider the broad category of "official" styles in opposition to everyday colloquial language, but they rather focus on the differences within the "official" type itself [e.g. Markowski, 1992] which mirror the diversity of the Polish culture [Bartmiński, 1993: 19]. There seems to exist a host of written styles ranging from colloquial used in writing, through

The names and definitions of the categories are also taken from Venuti [2008]. 
journalistic and scientific, to a varied "artistic" style encompassing and transforming all others [e.g. Bartmiński, 1993: 20; Wilkoń, 2000: 76]. ${ }^{2}$

Secondly, even if we try to consider the "official" written style as a coherent whole, as Venuti [2008] does with English in his work, the variety is not plain and communicative. Quite obviously, if we go back to the $17^{\text {th }}$ century, like Venuti, the dominant Polish style of the period is going to be the opposite of plain and informative: the $17^{\text {th }}$-century Polish was heavily dependent on inverted Latin syntax, with its long and complex sentence patterns, and incrusted with foreign vocabulary to show off the writer's or speaker's knowledge or wit [Głowiński, 2000: 59-60; Kostkiewiczowa, 2000: 534; Skubalanka, 1984: 83; Klimowicz, 2002: 42-43]. While the dominant style became somewhat less exuberant in the $18^{\text {th }}$ century (see Teresa Kostkiewiczowa [2000: 241] and especially Mieczysław Klimowicz [2002: 41-45], who writes about the opposition of the representatives of the Enlightenment against the baroque style of their predecessors), one would still be hard pressed to call it plain (e.g. Teresa Skubalanka [1984: 123-138] emphasises the continuation of long-established stylistic conventions throughout the $17^{\text {th }}$ and the $18^{\text {th }}$ centuries).

But even in today's Polish language, communicativeness and plainness are not the characteristics that are most sought-after in "official" styles. As Andrzej Markowski points out, the common characteristic of all the styles is "a certain artificiality", strong reliance on stylistic norms and conventions [Markowski, 1992: 118], as well as the use of complex sentence patterns, complicated syntactic constructions, nominal phrases, fixed expressions and metaphors, abstract and often foreign vocabulary [Markowski, 1992: 121-123].

Plainness and informativeness in Polish may be the prerequisite of some popular forms of the journalistic style, but critics usually do not require or indeed expect it in scientific or artistic texts. Scientific texts do not need to be highly readable or easy in Polish, not even on the

\footnotetext{
2 Some scholars state that, from the researchers' point of view, the position of the artistic style is special, as given its functions (aesthetic, autotelic), it requires completely different analytical tools than other styles of contemporary Polish [Markowski, 1992: 6]. Aleksander Wilkoń [2000: 76] and Ryszard Handke [1993: 135] also underline the special position of the artistic style as the one that encompasses all others. However, the style is never considered as dominant, only as different.
} 
stylistic or syntactic level. Andrzej Markowski even considers the fact that they are difficult to understand as one of their characteristic traits [1992: 155]. Aleksander Wilkon [2000: 64-65] describes the style of such texts as abstract, formalised, and impersonal in tone, with complex, hypotactic sentence structures and cohesion markers to make the thought process explicit.

What is interesting, some authors remark that in the past, humanistic texts used to be more "literary" in character, but nowadays they tend to mimic scientific texts with their dry tone, objectivity, and complete lack of expressive or subjective elements [Wilkoń, 2000: 65; Markowski, 1992: 170]. Academic styles have become specialised academic codes, too distant from everyday standard language. In Venuti's terms, it would therefore seem that the tendency in specialised academic writing in Polish is to become less plain, not more.

However, there is a marked difference in the way Polish scholars describe style. Venuti [2008] considers most examples of highly artistic "modernist" prose as an exception to the general rule of plainness. Polish scholars take the opposite view: they focus mainly on artistic prose, excluding popular literature as unworthy of their attention (without ever acknowledging it openly). Thus, Aleksander Wilkoń [2000] and Ryszard Handke [1993] consider the literary style as an artistic transposition of all other styles of the Polish language [Wilkoń, 2000: 76], an innovative, often deviant variety of language, deliberately violating systemic, pragmatic and communicative norms of the language [Wilkoń, 1999: 49; Handke, 1993: 135]. As we have mentioned above, Markowski excludes it completely from his considerations precisely because of this heterogeneity [1992: 6].

However, highly artistic prose may be sophisticated in style but it is not often the case in most of the literary production of our times. The type of contemporary literature that the scholars overlook - popular or even pulp fiction - is mostly characterised by the plainness of style that Venuti considers the dominant feature of the English written language [Głowiński, 2000: 410; Fulińska, 2003]. What is more, it is probably the most influential type of literature in that it is the most widely read. ${ }^{3}$

$3 \quad$ See e.g. bestseller lists published by the daily Gazeta Wyborcza on its website. The following numbers concern October 2015, but they are mostly representative of 
The plainness of these genres may well have two reasons: first, as literature of quick consumption, it focuses on content rather than form [Głowiński, 2000: 410]; second, the popular genres most read in Poland today are either translated from English or imitated by Polish authors (e.g. in the case of fantasy described in Guttfeld [2007], see below), and therefore their style may be "borrowed" from English as well.

The borrowing is sometimes clear also in other types of texts, e.g. scientific or popular scientific ones like textbooks, which are increasingly written to be more accessible to the reader rather than to show off the stylistic and intellectual superiority of the author [Gajda, 1999: 21]. ${ }^{4}$ However, as we will see below, it seems that in science, the hegemony of the English stylistic model meets some resistance.

To conclude my considerations of style, the traditional composition of the written text in Polish is rather far from the English plain style described by Venuti [2008]. However, in recent times the dominance of English seems to become visible in the domain of style as well, with much of popular literature, journalistic texts and popular scientific materials already imitating the English model, even though the new style is still often recognised as foreign. I will elaborate on that in the following section.

\section{Translation strategy}

The next element Venuti considers is translation strategy, in the US and in Britain predominantly domesticating, both in the case of style, and of cultural norms and values. Venuti is very strongly opposed to this strategy, identifying it with ethnocentric violence, and blaming it for increasingly xenophobic and imperialistic American tendencies [Venuti, 2008: 13].

such lists: in the belles lettres section, only three out of the ten books listed are not popular literature, and two of them (Ksiegi Jakubowe by Olga Tokarczuk and Wilk by Marek Hłasko) became bestsellers because of external factors that contributed to their popularity (political controversy surrounding Olga Tokarczuk, and the curious story of the accidental discovery of Hłasko's long-lost book) [Gazeta Wyborcza, 2016]. The non-fiction category has a similar proportion of popular books.

4 The difference between the traditional academic writing in English and Polish is pointed out e.g. in Duszak [1997: 13, 28]. 
Translation textbooks and courses in Poland usually seem to advocate foreignising translations: translators should not replace foreign names and culture-bound items [Hejwowski, 2004b]; or substitute Polish dialects for the original ones, etc. [Wojtasiewicz, 1957]. The scholars' argument is twofold: the readers should be able to enjoy the foreign flavour of the text and have the opportunity to learn new things about the foreign culture; and they should not be confused by the use of e.g. Polish culture-bound items in a foreign text, because it might make them think such elements were there in the original as well [Hejwowski, 2004a, 2004b; Wojtasiewicz, 1957]. Most literary translations from English, especially popular literary ones, follow the prescription, presenting the readers with a text that presupposes a great deal of familiarity with the British or American culture.

Examples of foreignising are not difficult to come by. In her analysis of translation techniques of culture-bound items from English into Polish, Magdalena Grala [2009, 2010] hypothesises that due to the globalisation of the Polish culture after 1989 (which she symptomatically equates with Americanisation) [2010: 67-69], translators of English and American novels into Polish use more direct techniques, requiring deeper knowledge of the source culture from the reader.

She offers a rather enlightening comparison of three translation series: The Grapes of Wrath, The Catcher in the Rye, and To Kill a Mockingbird, all translated twice, before and after 1989 [Grala-Kowalska, 2009: 153-156]. Her analysis shows that the expectations towards the readers have changed immensely, and that functional equivalent and hypernym $^{5}$ - the dominant techniques in the earlier translations - give way to more foreignising ones: transfer, syntagmatic translation, etc.

The picture gets even clearer in the next paper [Grala, 2010], where the author analyses translations of several contemporary novels. Here, the readers are clearly expected to have a near-native knowledge of the source culture: names of people and places, books, songs, movies, TV shows, institutions, even entire quotations are: transferred with no additional explanation or with a very short one; replaced with an already established equivalent in Polish; translated syntagmatically with or

5 Grala uses Krzysztof Hejwowski's classification of translation techniques [Hejwowski, 2004a: 76-85]. 
without explanation, and only seldom replaced with a hypernym [Grala, 2010: 71-73]. The more domesticating techniques, like functional or descriptive equivalent, are used infrequently [2010: 73-74].

The author supplements the paper with a list of examples [Grala, 2010: 77-82], and they are sometimes quite shocking in their foreignising force: while one can accept that the Polish readers are likely to know Tom Cruise or Walt Disney, it is surprising that they are also expected to be familiar with Wendy Wasserstein and Barry Norman or recognise the prestige associated with The New Yorker or Nine West:

\begin{tabular}{|l|l|}
\hline $\begin{array}{l}\text { Like Nicole Kidman when she } \\
\text { was divorcing Tom Cruise. }\end{array}$ & $\begin{array}{l}\text { Jak Nicole Kidman podczas ro- } \\
\text { zwodu z Tomem Cruise'em. }\end{array}$ \\
\hline $\begin{array}{l}\text { Only Walt Disney can guarantee } \\
\text { you a happy ending. }\end{array}$ & $\begin{array}{l}\text { Tylko Walt Disney może ci } \\
\text { zagwarantować szczéśliwe } \\
\text { zakończenie. }\end{array}$ \\
\hline $\begin{array}{l}\text { Someone like Nora Ephron or } \\
\text { Wendy Wassterstein was more } \\
\text { likely. }\end{array}$ & $\begin{array}{l}\text { Większe szanse miał ktoś w } \\
\text { rodzaju Nory Ephron lub Wendy } \\
\text { Wasserstein. }\end{array}$ \\
\hline You're not Barry Norman. & Nie jesteś Barrym Normanem. \\
\hline $\begin{array}{l}\text { It was unlikely I'd get hired at } \\
\text { the New Yorker directly after } \\
\text { high school. }\end{array}$ & $\begin{array}{l}\text { Zaraz po szkole mam mizerne } \\
\text { szanse na zatrudnienie w New } \\
\text { Yorkerze. }\end{array}$ \\
\hline $\begin{array}{l}\text { Wearing Nine West instead of } \\
\text { Manolo or jeans sold at Macy's } \\
\text { junior department but not any- } \\
\text { where on Barney's eight floor of } \\
\text { couture denim heaven. }\end{array}$ & $\begin{array}{l}\text { Noszenie Nine West zamiast } \\
\text { butów od Manola albo dżinsów } \\
\text { sprzedawanych w dziale } \\
\text { młodzieżowym u Macy'ego, a nie } \\
\text { gdzieś w raju markowych ciuchów } \\
\text { na ósmym piętrze u Barneya. }\end{array}$ \\
\hline
\end{tabular}

Grala concludes that this tendency shows that the Polish readers are not only expected to be familiar with the American and British culture, but also to share the source readers' values [Grala, 2010: 74-75].

A similar picture emerges from Guttfeld [2007], where the clear domination of the English and American cultures is analysed in Polish translations of science-fiction and fantasy novels. The author explains 
that the choice of the Polish translators of these books to foreignise is due to the genre being Anglo-American in origin; to the (young) target audience's knowledge of the original and of the source culture; and, interestingly, to the pressure of the copyright owners to transfer e.g. titles, toponyms, and anthroponyms in order to guarantee greater brand recognition [Guttfeld, 2007: 151-156]. The author adds that the dominance of the English and American culture in science-fiction and fantasy is such that Polish authors of original Polish fiction written in the genre often assume English-sounding noms de plume [Guttfeld, 2007: 152]. It can be hypothesised that the situation is similar with other popular genres originating or most widespread in the British and American cultures, like horror stories, thrillers, etc.

Therefore, it seems that, in translation from English into Polish, the foreignising strategies dominate, and exceptions are few and far between. ${ }^{6}$ Let us consider two such exceptions.

The first one is an interesting illustration of resistance to English stylistic models in scientific texts and it comes from the Manual of Emergency and Critical Care Ultrasound [Noble et al., 2007] and its Polish translation Podręcznik ultrasonografii w medycynie ratunkowej $i$ intensywnej terapii [2010]. ${ }^{7}$ The original is written in a very plain and simple style, clearly intended for beginning students of medicine, with very simple syntax, quite imaginative language and the bare minimum of medical terminology. The Polish version conforms to the Polish scholarly standard: it is full of Latin- and Greek-based medical terminology, long and complex sentences, and impersonal language. The translators went as far as to supply additional information (later largely transferred

6 This tendency to foreignise and to expect the Polish reader to deal with it is not only visible in translations from English. Danuta Kucała, in her comparison of a Czech and a Polish translation of a Spanish history book, notes that the Polish version contains many more Spanish elements than the Czech one [Kucała 2009: 173], and Jakub Jankowski shows that the Polish translation of a French but multilingual comic book Portugal is characterised by greater language variety than the Portuguese translation, despite the Polish language's greater distance to any of the original languages [Jankowski, 2015].

7 However, it is interesting to note that the version we discuss was supplied by the translators (medical professionals, not professional translators who would know which translation strategies are de rigueur at the moment), but subsequently underwent some foreignising interventions in the editorial process before publication. 
to footnotes by the editor) where they clearly thought the original was not in-depth enough. A characteristic example of the translators' resistant approach:

The globe is seen as a dark fluid-filled structure because the vitreous is largely fluid and so will appear dark on ultrasound [Noble et al., 2007: 175-176],

which became in the translators' version:

Gałka oczna widoczna jest jako hipoechogeniczna struktura, co wynika z dużej zawartości wody w ciele szklistym.

The brief example shows the substitution of everyday terms (dark fluid-filled structure - that is exactly what one sees in the accompanying image if one is not a specialist) is translated as hipoechogeniczna struktura, a choice which is more terminologically exact yet much less clear to a beginner; the fragment so will appear dark in ultrasound is omitted completely in the Polish version, judged probably too obvious for a medicine student.

As I have said above in the section devoted to Polish styles, the reader-friendly approach of the original violates the traditional Polish conventions of academic writing and could be therefore construed as less prestigious, too colloquial.

Another possible instance where the Polish cultural norm seems to prevail seems to be related to the difference in values between the source and the target culture. An interesting example of that is Tipping the Velvet/Muskajac aksamit by Sarah Waters, a popular British author of Victorian novels featuring lesbian protagonists. In the novel, a sex scene celebrating the happy ending of the main character's trials and tribulations - quite detailed in the original - coyly fades to black in the Polish translation:

At last, I felt her hand settle at the very wettest part of me, and she breathed against my ear. 'Do you care for it,' she murmured then, 'inside?' The question was such a gentle, such a gallant one, I almost wept. 'Oh!' I said, and again she kissed me; and after a moment I felt her move within me, first with one finger, then with two, I guessed, then three... At last, after a second's pressure, she had her hand in me up to the wrist. I think I called out-I think 
I shivered and panted and called out, to feel the subtle twisting of her wrist, the curling and uncurling of her sweet fingers, beneath my womb...

When I reached my crisis I felt a gush, and I found that I had wet her arm, with my spendings, from fingertip to elbow - and that she had come, out of a kind of sympathy, and lay weak and heavy against me, with her own skirts damp. She drew her hand free-making me shiver anew-and I seized it and held it, and pulled her face to me and kissed her; and then we lay very quietly with our limbs pressed hard together until, like cooling engines, we ceased our pulsings and grew still [Waters, 2009a: 428].

- Mogę? - szepnęla.

Odpowiedziałam westchnieniem. Po chwili poczułam w środku jeden palec, dwa, potem chyba trzy...

Gdy skończyłam, ciało Florence również przeszył spazm i opadła na mnie całym ciężarem. Przycisnęłam ją do siebie i obsypałam pocałunkami, a potem leżałyśmy ciasno przytulone, czekając, aż serca uspokoją nam się w piersi [Waters, 2009b: 381-382].

It is curious however that the translator or publisher decided to publish it at all - one would expect that if they found the book unacceptable, they would abandon the project altogether instead of censoring it, given that Waters is known precisely for the lesbian relationships she describes.

However, despite such unique and rare examples of domestication, it would seem that overall, foreignisation is the prevalent mode in translation from English into Polish, as we have seen in the examples supplied by Grala [2009, 2010] and Guttfeld [2007], and discussed above.

\section{Translation criticism}

As in the US and the UK [Venuti, 2008: 2 and ff.], the situation of translators in Poland is not improved by the lack of proper translation criticism in the press and other media, and by the fact that the translator's name is often omitted in reviews, information pieces and book advertisements, even those prepared by the publisher [Paszkiet, 2011: 11-12]. 
A brief analysis of a random issue of Nowe Ksiaziki (No 3 from 2006), a magazine offering reviews of recent publications in different genres, shows that translated books are reviewed quite often ( $c a$ 40\% of the books were translated, more than a half of them from English). The reviews list the name of the translator under the author's name and the title. However, otherwise the translator is completely invisible, the books are discussed as if they were written originally in Polish (which is typical of most Polish newspapers and magazines that print book reviews, also the more popular ones, like the daily Gazeta Wyborcza).

In the rare cases where the question of translation quality is even raised, the author of such a review is usually a renowned published author and a translator him- or herself (e.g. Jacek Dehnel's review of Alan Hollinghurst's Obce dziecko in Gazeta Wyborcza [Dehnel, 2012]).

\section{Translation market}

According to Venuti, one of the reasons of the poor situation of the translator and of translation in the US and in Great Britain is that only 2-4\% of books published in English are translations, with a surge in the 1960s, when the share reached up to 7\% [Venuti, 2008: 11].

What is more, according to UNESCO's Index Translationum, ${ }^{8}$ English is the most translated from (over 47,000 titles in 2008). In the same year, only 5347 books were translated into English. To compare, there were 433 books translated from Polish and 3620 - into Polish.

In a decade-by-decade comparison of the data available in the Index, the number of translations into English has been slowly climbing in the last 30 years ( $c a$ 46,000 in 1979-1988; ca 52,500 in 1989-1998; almost 64,000 in 1999-2008), but both in real numbers and in the rate of increase it is far outstripped by Germany, France, and Spain. In Poland, the number of published translations has been growing very fast: from 7641 in $1979-1988$, through 26,707 in $1989-1998$, to 42,262 in 1999-2008.

According to Polish Publishing in Figures 2012 [Seroka, 2013: 90, 97], over $19.5 \%$ of the books published in Poland after World War II

\footnotetext{
8 All Index Translationum data relate to the year 2008 - which seems to be the most recent year with complete data available.
} 
have been translations. Those from English have had the biggest share of the translation market ( $42.5 \%$ overall), with translation from Polish in the second place $(12.6 \%),{ }^{9}$ followed by German (10.5\%), Russian $(10 \%)$, and French (7.6\%).

For political reasons, one would expect that translations from Russian dominated before 1989. However, it was only true for the first post-War decade $(63 \%)$, with a sharp decline after the year 1955 (decade-by-decade: $26.6 \% ; 18.3 \% ; 16.6 \% ; 6.6 \% ; 1.8 \%$; and $1.8 \%$ ). Contrary to what one may have expected, translation from English has dominated ever since 1955, reaching around $20 \%$ of the translation market each decade in 1944-1985, when it took a sharp upward swing: $45.3 \%$ in the years $1986-1995$; $55 \%$ in $1996-2005$; and $51 \%$ in $2006-$ 2012 [Seroka, 2013].

In the year 2012, 6688 translations were published in Poland: 49.1\% of them from English, 8.9\% from German, 6.3\% from French, 3.9\% from Italian, and 1.3\% from Japanese [Seroka, 2013: 9]. One year later, the situation was even clearer: 59\% from English, 9\% from German, 7\% from French, 4\% from Italian, 3\% from Spanish, and 2\% from Russian [Dawidowicz-Chymkowska, 2015: 14].

The data would suggest that the situation of translators in Poland can be nothing if not comfortable. However, the size of the translation market does not ensure better translator status and higher translation quality. This has also a dark side, described eloquently by Sławomir Paszkiet in his Report on the Situation of Literary Translators in Poland [2011].

The author indicates that, after the political transformation in Poland, the book industry became completely market-governed. As a result, hundreds of new publishing houses emerged that put out thousands of translations which were often prepared hastily and unprofessionally: the increase in quantity was offset by a sharp drop in quality of both translations themselves and their subsequent preparation [Paszkiet, 2011: 13]. To save time and minimise costs, many publishers sacrifice translation quality, commission translations from inexperienced and incompetent translators, forgo the proofreading and revision stages. Some even go

The fact that Polish publishers need to translate Polish books into foreign languages (and that it is such a relatively widespread phenomenon) rather seems to confirm the thesis of the peripheral status of Polish culture. 
as far as to divide texts (even novels) among several translators, or to assemble a "translation" from samples made for free by naïve aspiring translators [Paszkiet, 2011: 15].

To understand better why the publishers do that we have to look at general readership figures in Poland, which clearly reflect the crisis of the Polish book industry. According to the Polish National Library Report for 2014 [Koryś et al., 2015], the number of "real" readers (i.e. those who read at least seven books a year) is $11 \%$, while $40 \%$ admit having at least consulted a single book in the past year, whether it was a dictionary, a cookbook or something more ambitious. No wonder the competition among publishers is cutthroat and the translators, along with proofreaders and revisers, suffer for it.

\section{Translator's financial and social status}

Venuti deplores the poor status of translators in English-speaking countries: their secondary position in comparison with original authors, the way they are paid, and their fees [Venuti, 2008: 8-9].

The situation in Poland is not much different in this respect. For most translators, literary translation is not their main source of income. They work full-time jobs in other segments of the economy, as translation fees of even the most famous of them would situate them beneath the poverty threshold [Paszkiet, 2011: 5]. Their fee is calculated in three ways: by text volume in standard pages (1800 characters) or publisher's sheets (40,000 characters); a share of the book's price (royalties); or fixed advance payment (usually dependant on the volume of the text) supplemented with a share of the sales price. The first method is the most widespread, and translators sell their copyrights definitively, thus giving up the possibility to derive profits from the translation in future [Paszkiet, 2011: 9].

The standard fee for a page ranges from about PLN 20 to 80, and for a publisher's sheet from $c a$ PLN 400 to 1700 . It is very rare that translators have the right to an additional fee in case the book sales reach a certain point [Paszkiet, 2011: 9]. As we can see, the discrepancies are rather great and the author does not indicate how many translators actually approach the higher level. If we compare it to the data provided by CEATL 
[Fock, de Haan, Lhotová, 2007/2008: 52], ${ }^{10}$ professional translators put out a bit over 1000 pages a year and they "earn much less than workers in the manufacturing and services sector. Those working for the lowest rates earn at best two thirds (and in nine countries not even $40 \%$ ) of what an industrial worker earns; and in six countries, even those working for the maximum rate do not earn more than two thirds of the average gross income in the manufacturing and services sector" [Fock, de Haan, Lhotová, 2007/2008: 69].

If we use the annual output and the fee per page reported by Paszkiet [2011: 9], we could estimate the annual fees of professional literary translators in Poland at anywhere between PLN 20,000 and PLN 80,000 (i.e. respectively PLN 1667 and PLN 6667 a month). The former - and very low - fee places them slightly above the minimal pay in $2011^{11}$ (which is PLN 1386 a month) [Serwis Gus, 2015]; the latter is almost twice the average income in Poland in 2011 (PLN 3400 a month) [Wynagrodzenia, 2014].

Other types of income calculation, i.e. royalties or share of the proceeds for the use of the work in all forms, are still very rare, so translators do not participate in the success of their book [Paszkiet, 2011: 16]. What is more, Poland is one of the very few countries in Europe without public lending rights, whereby literary translators profit from library lending of their translations [Paszkiet, 2011: 10].

As far as legal status is concerned, according to Article 16 of the Act from February 4, 1994 on Copyright and Related Rights, literary translators enjoy the same rights as original authors in Poland. However, there are two limitations here: first, in most standard translation agreements, translators waive their rights and definitively transfer the copyright to the publisher [Paszkiet, 2011: 8]; second, in provisions regarding social security and pensions, although literary translators do have the same rights (whose attractiveness is rather limited as it is) as original authors, in order to enjoy them, they have to obtain the legal status of a literary

10 Unfortunately, the survey does not cover the situation in Poland, but it remains a useful comparison tool. However, the numbers provided by CEATL are already estimates and informed guesses based on partial data, so the calculations I am offering have to be taken very carefully.

11 Since Paszkiet's report discusses data from 2011, I am using 2011 data as well for better comparison. 
translator first (via a Commission for Authors' Pension Entitlement) [Paszkiet, 2011: 6-7]. ${ }^{12}$ So in practice the equal rights apply to very few literary translators in Poland, which makes the situation in the country quite similar to that described by Venuti [2008] in the US and the UK.

Paszkiet also points out that many translation agreements in Poland are unclear, contradictory, injurious towards the translator, or even illegal, and rarely subject to negotiations [Paszkiet, 2011: 8]. He does not offer a comparison to other countries in this respect, but the CEALT report shows that in several European countries literary translators' associations have managed to introduce model translation agreements.

\section{Conclusions}

As the comparison of the situation in Poland and in English-speaking countries (as described in Venuti [2008]) shows, Venuti's line of reasoning cannot be reproduced in the Polish situation: the links between the factors he discusses (hegemony, dominating style, translation strategy, translator status etc.) are not so clear in the case of translation into Polish. According to the author, the cultural dominance of the US and British culture leads them to domesticate their translations and "hide" and neglect their translators. From this it would follow that the foreignising peripheral cultures should treat their translators better. However, as I have shown, this is manifestly not the case in Poland despite the popularity of the translated literature and the dominance of the foreignising strategies.

To conclude, while the translation market in Poland makes up almost half of the entire book market, there is not a single preferred style in written Polish, but rather a group of equally influential styles to choose from, and the dominant strategy applied by translators into Polish is foreignisation, the situation of the translator is not much improved compared to the situation in such hegemonic countries as the UK and the US. It would therefore suggest that Venuti's line of reasoning is not universal and only applies to the British and American situation. What is

\footnotetext{
12 It is important to note that, pitiful though the privileges are (the right to pay their own social contributions without the need to establish their own business), they are available exclusively to "certified" literary translators [Paszkiet, 2011: 6-7].
} 
more, it may put into question Venuti's claim about the straightforward link between the factors he discusses.

\section{References}

\section{Primary sources}

Noble, V.E., Nelson, B., Sutingco, A.N. (2007), Manual of Emergency and Critical Care Ultrasound, Cambridge University Press, Cambridge.

Noble, V.E., Nelson, B., Sutingco, A.N. (2010), Podręcznik ultrasonografii w medycynie ratunkowej i intensywnej terapii, transl. W. Mielnicki, T. Kuniej, MediPage, Warszawa.

Waters, S. (2009a), Tipping the Velvet, Virago, London.

Waters, S. (2009b), Muskajac aksamit, transl. M. Gawlik-Małkowska, Prószyński i S-ka, Warszawa.

\section{Secondary sources}

Bartmiński, J. (1993), "Wprowadzenie”, in: Bartmiński, J. (ed.), Encyklopedia kultury polskiej XX wieku, t. 2: Współczesny język polski, Wiedza o Kulturze, Wrocław, pp. 13-23.

Dawidowicz-Chymkowska, O. (ed.) (2015), Polish Publishing in Figures 2013, Biblioteka Narodowa, Warszawa, [on-line] www.bn.org.pl/download/document/1423045683.pdf - 8.12.2015.

Dehnel, J. (2012), “"Obce dziecko» Hollinghursta: potęga (złego) przekładu”, Gazeta Wyborcza, 9.10.2012, [on-line] http://wyborcza. pl/1,75475,12633873,_Obce_dziecko_Hollinghursta_potega_zlego_ przekladu.html - 13.03.2016.

Duszak, A. (1997), "Cross-cultural academic communication: A discoursecommunity view", in: Duszak, A. (ed.), Culture and styles of academic writing, Mouton de Gruyter, Berlin, New York, pp. 11-39.

Fock, H., de Haan, M., Lhotová, A. (2007/2008), Comparative income of literary translators in Europe, CEATL, Brussels, [on-line] www.ceatl.eu/docs/ surveyuk.pdf - 8.12.2015.

Fulińska, A. (2003), "Dlaczego literatura popularna jest popularna?", Teksty Drugie, 4, pp. 55-66, [on-line] http://rcin.org.pl/Content/53850/ WA248_70220_P-I-2524_fulinska-dlaczego.pdf - 11.03.2016. 
Gajda, S. (1999), “Język nauk humanistycznych”, in: Pisarek, W. (ed.), Polszczyzna 2000, Ośrodek Badań Prasoznawczych, Uniwersytet Jagielloński, Kraków.

Gazeta Wyborcza (2016), "Bestsellery «Wyborczej»: Niepokonany Grey, silni Bonda i Lagercrantz. Debiut Tokarczuk", [on-line] http://wyborcza.pl/1,75475,19754671, bestsellery-wyborczej-niepokonany-greysilni-bonda-i-lagercrantz.html - 12.03.2016.

Głowiński, M. (2000), "Barok", in: Głowiński, M., Kostkiewiczowa, T., Okopień-Sławińska, A., Sławiński, J. (eds.), Słownik terminów literackich, Ossolineum, Wrocław-Warszawa-Kraków, pp. 58-60.

Grala, M. (2010), "Elementy kulturowe a strategie thumacza w przekładzie współczesnej prozy angloamerykańskiej”, in: Hejwowski, K. (ed.), Ttumaczenie. Leksyka, frazeologia, styl, Instytut Lingwistyki Stosowanej UW, Warszawa, pp. 67-82.

Grala-Kowalska, M. (2009), "Wstęp do teorii thumaczenia O. Wojtasiewicza w dobie globalizacji kulturowej”, in: Hejwowski, K., Szczęsny, A., Topczewska, U. (eds.), 50 lat polskiej translatoryki, Instytut Lingwistyki Stosowanej UW, Warszawa, pp. 151-162.

Guttfeld, D. (2007), "Anglocentryzm w polskich thumaczeniach anglojęzycznej fantastyki: tendencje, przyczyny, skutki”, in: Szczęsny, A., Hejwowski, K. (eds.), Językowy obraz świata w oryginale i przektadzie, Instytut Lingwistyki Stosowanej UW, Warszawa, pp. 151-158.

Handke, R. (1993), "Styl artystyczny”, in: Bartmiński, J. (ed.), Wspótczesny język polski, Wiedza o Kulturze, Wrocław, pp. 135-145.

Hejwowski, K. (2004a), Kognitywno-komunikacyjna teoria przektadu, Wydawnictwo Naukowe PWN, Warszawa.

Hejwowski, K. (2004b), Translation: Cognitive-communicative approach, Wydawnictwo Wszechnicy Mazurskiej, Olecko.

Jankowski, J. (2015), "Bermanowskie superpozycje językowe i egzotyzacja kontra komiks Cyrila Pedrosy Portugalia", Między Oryginatem a Przekładem, 30, pp. 107-125.

Klimowicz, M. (2002), Oświecenie, Wydawnictwo Naukowe PWN, Warszawa. Koryś, I., Michalak, D., Chymkowski, R. (2015), Stan czytelnictwa w Polsce w 2014 roku, Biblioteka Narodowa, Warszawa, [on-line] www.bn.org.pl/ download/document/1428654601.pdf - 8.12.2015. 
Kostkiewiczowa, T. (2000), "Styl makaroniczny", in: Głowiński, M., Kostkiewiczowa, T., Okopień-Sławińska, A., Sławiński, J. (eds.), Słownik terminów literackich, Ossolineum, Wrocław-Warszawa-Kraków, p. 534.

Kucała, D. (2009), "Czy zachowanie obcych elementów w przekładzie może być korzystne?”, Między Oryginatem a Przektadem, 15, pp. 173-183.

Markowski, A. (1992), Polszczyzna końca XX wieku, Wiedza Powszechna, Warszawa.

Paszkiet, S. (2011), Raport o sytuacji tlumaczy literackich w Polsce, Instytut Książki, [on-line] http://stl.org.pl/wp-content/uploads/2015/03/Raport_o_ sytuacji_tlumaczy_literackich_Paszkiet.pdf - 8.12.2015.

Seroka, A. (ed.) (2013), Polish Publishing in Figures 2012, Biblioteka Narodowa, Warszawa, [on-line] www.bn.org.pl/download/document/1377611929.pdf -8.12 .2015 .

Serwis Gus (2015), [on-line] www.zus.pl/default.asp?p=1\&id=1019 $-12.03 .2016$.

Skubalanka, T. (1984), Historyczna stylistyka języka polskiego, Ossolineum, Wrocław-Warszawa-Kraków-Gdańsk-Lódź.

UNESCO (2003-2014), Index Translationum, [on-line] http://portal.unesco.org/

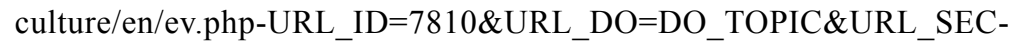
TION=201.html -8.12 .2015 .

Venuti, L. (2008), The Translator's Invisibility. A History of Translation, Second Edition, Routledge, Exon.

Wilkoń, A. (1999), Język artystyczny: studia i szkice, Śląsk, Katowice.

Wilkoń, A. (2000), Typologia odmian językowych wspótczesnej polszczyzny, Wydawnictwo Uniwersytetu Śląskiego, Katowice.

Wojtasiewicz, O. (1957), Wstęp do teorii tlumaczenia, Zakład im. Ossolińskich, Wrocław.

Wynagrodzenia (2014), [on-line] http://wynagrodzenia.pl/gus_roczne.php -8.12 .2015 .

\section{SUMMARY}

In the introduction to his book The Translator's Invisibility, Lawrence Venuti discusses the condition of the translator and of translation in contemporary America. In the country, translation is not a valued activity, 
translated texts are domesticated, and translators are expected to remain invisible.

The article discusses how Venuti's diagnosis applies to the situation in Poland, with its much more peripheral or even culturally subordinated status; whether the causes of translator's invisibility, listed by Venuti, appear in translation into Polish; how the position of translation and of the translator is influenced by the target culture's peripheral character; and whether there is a straightforward link between cultural hegemony and translation strategy.

Key words: translation, translator status, cultural hegemony, peripheral culture

\section{STRESZCZenIE}

Dominujące i peryferyjne kultury w tlumaczeniu a status tlumacza We wstępie do swojej książki The Translator's Invisibility Lawrence Venuti omawia status tłumacza i tłumaczenia we współczesnej Ameryce, gdzie nie jest to zajęcie poważane, przekłady ulegają udomowieniu, a od thumaczy oczekuje się, że pozostaną niewidoczni.

Artykuł stanowi próbę refleksji nad diagnozą Venutiego - nad tym, czy da się ją zastosować do sytuacji w kulturowo peryferyjnej Polsce, czy przyczyny niewidoczności thumacza, zaproponowane przez Venutiego, są obecne także w przekładach na polski, jak peryferyjny status kultury przekładu wpływa na pozycję tłumaczenia i tłumacza, a także czy istnieje prosty związek między hegemonią kulturową a strategią thumaczeniową.

Słowa kluczowe: tłumaczenie, status tłumacza, hegemonia kulturowa, kultura peryferyjna 